\title{
Marca Peru: Representations and Exclusions of the Afro- Descendant Population from the Official Narrative of the Peruvian Government
}

\author{
Ana Lucía Mosquera Rosado • Pontificia Universidad Católica del Perú
}

\begin{abstract}
The article will examine the representations of Afro-Peruvians in the video "Peru Nebraska," a documentary produced as part of the launching of the advertising campaign of Marca Peru, a national branding project elaborated by the Peruvian government in 2010 . By examining the participation of the Afro-descendant population in this audiovisual piece, the document will relate these representations to the discourses of diversity, race, and citizenship in Peru. The article will also explore the nature of the discourses of ethnic and racial diversity in Peru in the new construction of the national and will evaluate the construction of the social imaginaries to represent Afro-Peruvians and construct blackness in a nation that has maintained mestizaje at the center of its identitarian process. In order to do so, it will focus on examining how Afro-Peruvians (dis) appear in the new narratives of peruanidad and how these images differ with the uprising official discourses of diversity and multiculturalism. By examining the famous short film "Peru, Nebraska," the article will analyze issues related to citizenship and inclusion of the Afro-Peruvian population, related not only to the acknowledgment of their existence, but also to their position in the construction and development of the national identitarian processes.
\end{abstract}

$\mathrm{P}$ eru is often portrayed as a mestizo nation, inheritor of the ancestral Inca past and full of traditions and cultural expressions that make it exotic and unique. The narratives that built this national discourse were focused on the merge of different ethnic traditions and the portrayal of Peruvians as a culturally hybrid and homogeneous people.

This is the country that I was born and raised in, a country with established social structures that privileged criollo ${ }^{1}$ white elites and vanished the opportunities for non-white groups to highlight their own culture or construct their own identities. In Peru, el país de todas las sangres "the country of all bloods," miscegenation discourses are used to diminish the empowerment chances for racial minorities and ignore the inequalities that affect them.

These discourses also influenced Peruvian media, which constantly fails to address all Peruvians in their multiple and diverse identities and sells an idea of beauty and success related to a color of skin to which most Peruvians hardly identify with. For centuries, the media has determined how we are supposed to be, and from being exposed to this, we have learned what to do to be better, smarter and prettier.

The popular media has shaped our ways of seeing our society, our country and ourselves. But it has also shaped the ways in which the state visually constructs peruanidad, and how a government that is supposed to represent all its citizens contributes to making us even more invisible, while appropriating specific cultural elements and exoticizing its ethnic minorities.

The current essay will examine the representations of Afro-Peruvians within the new official national narratives centered under the national brand Marca Peru through the video "Peru, Nebraska." This national brand was created in 2010 as a "tool that seeks to boost tourism, exports and attract investment; and effectively transmit the value proposition of our country" (Promperu, 2010). The promotion of Marca Peru did not only include the creation of advertising pieces, but also the entitlement of ambassadors of the brand, that are usually famous figures in the country with a visible presence in the arts, the cuisine, and the Peruvian culture. 
The video "Peru, Nebraska" is a part of a nation branding project proposed by the Peruvian government to promote the assets of the nation and bring the attention of the world to the multiple commodities the country has to offer.

By examining the famous short film "Peru, Nebraska," I will analyze issues related to citizenship and inclusion of the Afro-Peruvian population, related not only to the acknowledgment of their existence, but also to their position in the construction and development of the national identitarian processes. In order to do so, I will focus on examining how Afro-Peruvians (dis)appear in the new narratives of peruanidad and how these images differ with the uprising discourses of diversity and multiculturalism.

\section{Media Representation of Afro-Peruvians and the National Identity Formation}

The representation of Afro-descendants in the media has been addressed by scholars that focused on the images and depictions of ethnic minorities and relate these to the racial and ethnic discourses generated in the Americas. While most of this work focuses on other countries in the region, they provide an important overview of the relationship between media, race and citizenship.

In relation to institutionalized media discourses, N'bare N'Gom evaluates the ways in which African heritage has been depicted in the media and how these representations have influenced the construction of the "peripheral otherness" that affects black people in the Americas. In the essay "The Kidnapping of Identity: Media Discourses and Trans Africanism in the Americas," N'Gom evaluates the construction of discourses of otherness and its relation to the dominance of hegemonic groups, who had the power to construct and determine the position of the non-dominant minorities in a national context.

Consequently, these discourses have influenced the ways in which Afro-descendants in the Americas form their identities and integrate into a big national sphere. Referring to what Frank Ukadike identifies as "fragmented identities," he examines the ways in which these populations have been incorporated into the national spheres as insignificant and irrelevant subjects.

The dominant discourses that perpetuated the negative representations of Afro-descendants were created under Eurocentric ideologies and incorporated into the national discourses, which caused the disconnection of the Afrodescendant population from the nation-state formation, through "a systematic process of banalization and historic responsibility liberation" (N'Gom 19).

In this context, N'Gom evaluates the responsibility of the media in the promotion of these discourses, the negative representation through the perpetuation of racist discourses and the distortion in the depictions and images of the people of African descent, by evaluating the images of blacks associated with intellectual incapacity and lack of articulation, identified as common characteristics of the way in which they are represented throughout the Americas.

According to the author, the Afro-descendants in the region are positioned as inferior subjects, disconnected from history, dispossessed from their own culture and silenced in social and institutional spaces. This discourse, identified by N'Gom (23) as a "discourse of omissions and distortions" has become a structural representation without any possibility of modification.

Another scholar that examines the relationship between media and race is Salome Aguilera, who provides an interesting overview of the role of the media in the process of racial representation in Latin America. In her article, "Las cargas de la representación: Notas sobre la raza y la representación en el Cine Latinoamericano," Aguilera provides a close approximation to racial representation, through the analysis of audiovisual material to address the concepts of race and ethnicity in Latin America.

In order to do so, she positions Latin America as a very diverse and multiracial region, where the projects of ideological whitening were used as a strategy to build national identities that blurred the existence of distinct ethnic groups. These new national identities, then, had as an objective "to unify a heterogeneous and unequal population under a unique nationalist flag that resignified the supposed source of shame as a positive symbol of distinctiveness" (Aguilera, 137).

With this in mind, the author focuses on the analysis of racial formation in Mexico, Cuba, and Brazil, examining the ways in which cinematographic productions address race and ethnicity from a historical perspective, to show how these countries' racial ideologies influenced the way media represents minorities.

Aguilera uses racial formation theories to develop her analysis, she also focuses on addressing cultural appropriation -mainly of indigenous and Afro-descendant populations- not only as a part of the national identity formation process, but also as a way to dispossess these populations of their cultures and therefore, the possibility to constitute as an ethnic group and claim a distinctive cultural identity.

Taking films from the three countries previously mentioned, the article gives a critical reflection on race representation in the media and most specifically, on historical films. In this essay, the author is critical about the fact that these films, mostly historically set in the colonial period, locate racism and racial tensions in the past, without acknowledging its contemporary manifestations. For Aguilera, this is not an exclusive characteristic of historical films, since most of the Latin American media avoid addressing these issues and perpetuate the construction of imaginary social scenarios that privilege whiteness and do not include racial and ethnic minorities. 
Aguilera also shows the way in which racialized subjects appear in contemporary cinematographic productions, and how these appear as a symbol of national identity to avoid the addressing of racial issues affecting their lives (Aguilera 143). The analysis proposed by Aguilera, thus, allows the reader to understand the consequences of the discourse of mestizaje and its penetration in the construction of media images that vanish racial tensions and appeal to the construction of a national consciousness instead.

The contradictions of these representations, then, rest on the fact that the use of racial and ethnic minorities as symbols of national identities and oversimplify their presence in the aims of recognition and resignification, as a strategy to dismiss the addressing of racial discrimination and hide a difficult socioeconomic reality.

The relationship between blackness and citizenship in Peru is an issue addressed by very few authors. However, there is remarkable work written about the ways in which Afro-Peruvian identity is located within the frame of nationalism and peruanidad. One of the authors who analyzes how the discourse of multiculturalism and inclusion results in the exclusion of the Afro-Peruvian population is Shane Greene, who presents a detailed analysis of the place that this population has in the national identity in "Todos Somos Incas, Todos Somos Iguales: Dilemmas of Afro-Peruvian Citizenship and Inca Whiteness in Peru."

Greene evaluates the practice of multiculturalism as a new discourse that uplifts racial and ethnic diversity and recognize it as an important component of the national identity. However, he argues that the issues regarding the Afro-Peruvian citizenship are not fully addressed by this new approach and leave this population outside of the national spectrum.

By examining the ways in which the national discourse in Peru has been drawn, Greene is able to establish a relationship between the prevalence of the Inca culture when defining the national identity, making the Afro-Descendant population invisible and unrecognized. To the author, the Peruvian national identity positions the indigenous populations as authentic representatives of Peruvian past and are, therefore, the ones who represent Peru as a nation and Peruvian People (Greene 138). The Afro-Peruvians, thus, are represented as not Incas and not Indians, in an ambiguous position in which their contributions to the nation are not recognized as they appear as isolated actors to the national development process.

Tanya Golash-Boza also analyzes the discourses of mestizaje and its impacts in the conception and understanding of blackness in the country in Yo soy negro: Blackness in Peru, a work that resulted from her ethnographic fieldwork in rural and urban Afro-Peruvians communities.

To Golash-Boza, Afro-Peruvians have participated in the nation in different ways than the indigenous population, and these differences are necessary to understand the conceptualization of blackness in the country (Golash-Boza 60). To her, while mestizaje involved indigenous ancestral knowledge, it sought to erase black cultural forms progressively, transforming their present into non-transcendental for the national identity.

Because of it, the notions of indigeneity and blackness are drawn with completely different objectives and had opposite outcomes, since black identity was restricted to racial and physical features and the Afro-Peruvian culture was unacknowledged. Thus, the national identity construction processes used acculturation to dispossess the black population in Peru of their own forms of culture and include them in the hegemonic criollo identity, while appealing to assimilation processes to civilize and integrate indigenous people.

These strategies were accompanied by processes of whitening and unofficial black eradication policies that reduced the black population in very few years, proving how the national project intended to eliminate them from the country and imagined them "out of the nation" over the course of some decades (Golash-Boza 64).

These construction processes also influenced the way in which the black population is portrayed in the media, and the depictions that affect the current dynamics of identity, representation and recognition among Afro-Peruvians. In the chapter "Black is beautiful or white is right?" GolashBoza gathers the experiences of the people of El Ingenio, an Afro-Peruvian rural village, in relation to race, racism and the invisibility of the black population in the popular media.

To her, Afro-Peruvians are misrepresented, folklorized and associated with positions of surveillance, since, as she states that "Blacks are often portrayed on Peruvian television as subservient, unintelligent, and exotic" (GolashBoza 166). For instance, telenovelas -considered as one of the most popular genres of Peruvian television- reproduce the established hierarchies portraying blacks in positions of submission, since these representations reflect the normalization of race dynamics and the uplifting of whiteness.

These representations have been internalized and accepted by the Afro-Peruvians, which complicates the identification of these negative depictions in the media and normalizes the common association of blacks with surveillance.

In relation to other sources of popular media, the scenario is not different. Golash-Boza addresses the issue of the advertising industry in which $70 \%$ of the participants are white; despite the fact that, in Peru, white people would be considered an ethnic minority. However, she highlights that the access Afro-Peruvians have to international media allows them to associate blackness with success and beauty; and to identify with prominent figures.

Finally, she references the media representations to analyze their influence on the common beliefs that the AfroPeruvians have about themselves, referring to some testimonies that equated blackness with ugliness and lack of 
intelligence. These prejudices also affected the way AfroPeruvians saw uncommon representations that located blacks in power and professional positions (Golash-Boza 163).

\section{The Images of the Afro-Peruvians as a Part of Marca Peru}

As these authors previously mentioned, the popular media often present distorted images of Afro-Peruvians and function as a means to reproduce racial stereotypes and negative representations of these populations.

In contrast with this, the Peruvian government has focused on promoting multicultural policies that recognize and valorize the ethnic and racial diversity of the country, considering it as an asset for development. This official discourse, however, has not fully addressed this diversity, thus maintaining traditional national discourses and ignoring the contributions of the non-indigenous ethnic minorities.

Taking this into consideration, this essay will present an analysis of the video "Peru, Nebraska," a piece created as a part of the national government campaign Marca Peru to promote the Peruvian cultural heritage and to evoke the national sentiments and identities of Peruvians, becoming into one of the most memorable and popular pieces over the last decade.

The video documentary was a huge success in Peru and outside of the country, and it presented an innovative idea: the ad is set in Peru, a small town in Nebraska, United States, with 589 new Peruvians that needed to learn about their country. By promoting the cultural assets of the country, the video sought to promote Peru in the international sphere and at the same time appeal to the national sentiments of all Peruvians.

Likewise, the reception of the video and the campaign was positive among Peruvians, since the appeal to common cultural elements generated an emotional attachment and reinforced the national identity. As Mathias Schmitz states, the campaign was created to appeal to the collective identification of Peruvians, as the creators expected for it to have a positive impact on national pride, trust and perceived internal coherence (329).

The video was divided into sections, dedicated specifically to the things Marca Peru wanted to offer. The first scene shows the city of Peru, Nebraska resting quietly and a red and white bus -like the colors of the Peruvian flagmaking its way into the town to show its inhabitants what it feels like to be Peruvian. When the bus gets to the main square of the city, the bus door opens and the ambassadors start to get off, one after the other. They all are identified by their names and their professions, but the first scenes show a homogeneous representation of the Peruvian white elites: is it possible to identify famous chefs, actors, comedians and athletes with similar phenotypical characteristics that adjust to white standards of beauty.

After the first frames, the famous Quechua actress Magaly Solier makes her way down the bus, and after her, the famous indigenous singer Dina Paucar and her harpist appear in the scene. They are all identified with name tags digitally inserted next to their faces. The next people to get off the bus are the musicians of Peru Negro, the most popular Afro-Peruvian musical group in the country, but none of their names are mentioned in the video, not even in their later appearances.

In this very first moment, they appear as outsiders, as they are not identified as a part of the group of ambassadors, participating as an accessory figure and not having a leading role like the rest of the ambassadors. Moreover, the tag introduces them as "Musicians and dancers of Peru Negro," a detail that further deepens their placement as others, since they appear as an unrecognized element that does not need to be specified.

When the rest of the ambassadors get out of the bus, they proceed to read the new Peruvians their rights as such. The first thing that comes is the right to eat delicious food. And the first dish they try, is, paradoxically, the anticucho, a dish with a recognized Afro-Peruvian origin (Chocano and Rospigliosi 24). The food is shared with the other Peruvians and the white ambassadors lead most of the dialogues and explanations about the origins of the food, interacting with the people to make sure they like what they are eating. Afro-Peruvians appear in these frames delivering the food, but their faces are not shown, and they do not have any dialogues.

Throughout the 15-minute documentary, it is possible to see how the elements of Andean and Amazonian indigenous cultures are presented to the Peruvians as an exotic element that should generate pride and a sense of belonging. However, despite the inclusion of three people who identified themselves as indigenous, there are very few moments in which they are leading the interaction and sharing their culture with the people of Peru, Nebraska.

The video continues with the new Peruvians enjoying traditional food, cultural expressions and even sports that are representative of the country. As a part of the interaction, the narrator introduces the scene in which the AfroPeruvians appear: they are presented as the group of people who would change the quiet Sunday afternoons in Peru Nebraska, and fill them with "rhythm and flavor". For this to happen, they would do an exchange taking the city sheriff to better the traffic flow in Lima, and bringing Peru Negro to "better their blood fluid."

The following frame shows a dancing club in which a group of people is doing a line dance of country music, and in which the dancers and musicians of Peru Negro burst in abruptly to invite them to dance Afro-Peruvian music. The 
scene continues with alternate scenes between the dancers making a presentation while the people in the club stare at them, the new Peruvians receive lessons to learn to play the cajón ${ }^{2}$, and a final scene in which the dancers of Peru Negro integrate the new Peruvians and do a dance together.

Despite being devalued and minimized by many, music has been a weapon of resistance and existence. As a consequence of the enslavement process, Africans and descendants of Africans who arrived in Peru were stripped of an African culture of their own due to processes of Hispanicization and acculturation, and therefore, lost the opportunity to continue with African cultural traditions. Because of it, one of the most important manifestations of people of African descent in Peru is their art, which allows them to exist and express themselves in a unique way to tell their story, to be a means of expression and protest and to leave indelible marks of their own existence.

However, without taking this into consideration, the scene is set in a vibrant environment in which AfroPeruvians appear as an exotic group of people to bring joy and entertainment with any allusion to the cultural meaning of the Afro-Peruvian music.

After that short scene is over, there are a couple more scenes in which it is possible to see Afro-Peruvians. They are included in the frames almost as extras, without any type of participation or dialogues. Even in the scene of the performance of Peru Negro, none of the members of the group gets to read the Peruvians their rights, like in the other scenes, and the description of their intervention is led by the narrator, who does not provide any type of context or specification in relation to the performance they are about to make.

In this context, it is possible to note a slight difference in the way in which Afro-Peruvian culture is represented and portrayed, in relation to the level of detail that these two cultural expressions - the performance of AfroPeruvian festejo and the cajón lessons- have when compared to the indigenous traditions.

For instance, traditions like the preparation of ancestral pachamanca are fully addressed in their connection to the land and the indigenous history; and the famous singer Dina Paucar gently introduces huayno, a popular Andean music genre. Moreover, the indigenous traditions are fully addressed and explained in a more interactive dynamic in which the new Peruvians are allowed to acquire new knowledge about the significance of these practices in the country.

The video, thus, does not only fall into the stereotyping of Afro-Peruvians but also in placing them as silenced and isolated actors without significant participation in a nation's branding commercial video. The way in which Afro-Peruvians are portrayed is a sign of a lack of intention to adequately and pertinently depict an ethnic minority population that has been traditionally misrepresented in the media and invisible in the national history and identitarian processes.

The black Peruvians are represented as exotic pieces that bring flavor and joy, but do not possess significant cultural elements worth mentioning, thus reinforcing the stereotype and folklorization of Afro-Peruvians that relates them exclusively to music and dance. As Matthew Hughey refers, "visibility and acceptance are not a guarantee of legitimacy or decency" (544). The false inclusiveness of the Afro-Peruvian population responds, in this case, to the need to represent diversity in a superficial way to maintain the idea of mestizaje as the main characteristic of the Peruvian.

In this piece, the Afro-Peruvians appear as outsiders in an already established national discourse that recognizes its mestizo and indigenous roots, but denies the specific cultural forms and traditions of the people of African descent.

The blurry presence of Afro-Peruvians in this video is one of the effects of the intentional disappearance of Peruvians of dark skin from the images of my country. To the Peruvian people, our blackness must be dismissed and diminished, and our existence should not be addressed or explained, leaving us in a state of permanent invisibility.

\section{Out of the Images and Out of the Society: An Existence of Multiple Exclusions}

If you are an Afro-Peruvian, it is not difficult to feel a stranger in your own land. Being an Afro-Peruvian means being frequently questioned about your belonging, your existence and your importance in a place in where your ancestors contributed despite being dehumanized and diminished in their dignity and their rights.

Many of the scholars that study racism in Peru coincide when affirming that most of the representations of the AfroPeruvian population is associated with negative characteristics and that they are seen from a biased perspective based on stereotypes and prejudices. According to Suzanne Oboler (62), this negative appearance in the social imaginary is recognized by Peruvians regardless of their race, ethnicity, class, gender, age or level of interaction with Afro-Peruvians. In this same line, Mercedes de la Cadena addresses the contradictions of a mestizo identity that is not officially recognized, but rather operates implicitly in the understandings of peruanidad, defining mestizaje as a complex ideology created to diminish the visible presence of racialized systems of differentiation and a project that never sought to "uplift the inferior races" (De la Cadena 4).

This imaginary is maintained through the reproduction of negative images of Afro-Peruvians in the media and the lack of recognition of their cultural asset, their history beyond slavery and their participation and contributions to the formation of the nation. 
In this context, the publicity campaign of Marca Peru and the video "Peru, Nebraska" are located on the logic of stereotyping images of the Afro-descendant population and seem to be the result of a last-minute addition or an official requirement in concordance with the multicultural approach that must be implemented inside of all the governmental agencies.

The short-film, that is supposed to portray the value of the multiculturalism and multiethnicity of Peru, fails to include this characteristic in a constructive, representative way; and continues to position the Afro-Peruvians as an accessory made for the collective entertainment of the others, whose relevance must be limited to their natural abilities to bring rhythm, color, and flavor to the Peruvian society.

In the few minutes in which they appear, the AfroPeruvian bodies are exposed as a means for entertainment, reinforcing the prejudices that lay the foundations for the spreading of racist ideologies that place them as capable of performing trades strictly related to the use of their bodies, and that historically "condemned them to certain social places that they could not cross" (Arrelucea, 164).

The portrayal of the Afro-Peruvians in "Peru, Nebraska" contributes to the constant exoticism that identifies the Afro-Peruvian population as picturesque, colorful and vivid, and that should always be ready to please the needs for fun of the rest. In this piece, the Afro-Peruvian culture is presented detached from its meaning and its relevance to the survival and resistance of our peoples, and is restricted to an isolated action that does not respond to historical processes and collective identity construction of the AfroPeruvian population.

Unfortunately, this depiction is not far from the social imaginary that is created around us: in this video, the Afro-Peruvians appear as isolated actors that do not seem to blend in with the discourses of Peruanidad and coexist separated from the rest of the nation.

This video is a sample of how Peruvians think of the Afro-descendants as Others, and how the new discourses of diversity seem to give them visibility, but actually depict them superficially, recurring to the classic stereotyping images that have identified them for decades.

The commodification of Afro-Peruvian cultural identity is an example of this. Contradictorily, while the video embraces the cultural traditions like the traditional dances and the food to appeal to icons to promote the national identity, it silences the Afro-Peruvians and takes away the opportunity to be those who transmit the expressions of their own culture.

The intercultural discourse transmitted through this publicity piece destined to reinforce national pride is a perfect example of the shortcomings in the recognition of a population that seems to be on the margins of society and that is selectively visible at the convenience of the interests of a State that has failed to grant us a place in the perfect picture of Peru.

The commodifying way in which the Afro-Peruvians are depicted is a sign of our lack of recognition in a country that was built on our shoulders and at the cost of our pain, that hides our invisibility with images that stereotype us and denies us the possibility of being seen as active agents in the development of the nation.

Marca Peru has continued to develop campaigns to promote the identification with the cultural heritage of the country and to evoke national sentiments in Peruvians. Since many of these campaigns maintain a standard representation of Peruvians and focuses on depicting Peru as a mestizo nation, some of the last actions have included AfroPeruvian music as an integral part of the Peruvian identity. However, the number of Afro-Peruvians that appear or lead these videos is still low and, in some cases, null, thus continuing with the logic of commodification of the cultural expressions of the Afro-Peruvians without including them as an important part of the visual narrative of Marca Peru.

Because of it, it is important that the future research should focus on the development of Marca Peru and the use of Afro-Peruvian characters as figures of peruanidad, to evaluate the development of the intercultural approach in the production of national branding advertising visual material that appeals to the reinforcement of national identity. 


\section{NOTES}

1. Though there are many definitions of criollo that have changed over the decades, it is necessary to define criollo in accuracy with the development of this research. In Peru, criollo has been used as a form of both racial and social categorization since the 16th century, as a criollo was a person born in the country that descended from Spaniards. However, this criteria was complemented with a social component since the existence of criollos allowed the configuration of a social hierarchy that distinguished not only as racially superior -as they descended from white Spaniards- but also contributed to the location of the non-white minorities in the very bottom of the social pyramid (Nugent 42). During the years after the independence of Peru and the construction of the new Republic, criollo remained as a socially accepted concept that described the predominantly white elite that set and determine the cultural traditions and social dynamics of the city.

2. The cajón was recognized as an Afro-Peruvian origin instrument by the Ministry of Culture in Peru.

\section{WORKS CITED}

Agüero, Jose, Martin Bustamante, Owan Lay, Ana Lucía Mosquera and Gustavo Oré. Derechos de la población Afroperuana: revalorando la cultura afroperuana desde la gestión pública. Ministerio de Cultura, 2015.

Aguilera Skvirsky, Salomé. “Las Cargas De La Representación: Notas Sobre La Raza y La Representación En El Cine Latinoamericano." Hispanófila, vol. 177, no. 1, 2016, pp. 137-154., doi:10.1353/hsf.2016.0034.

Arrelucea, Maribel and Jesús Cosamalón. La presencia afrodescendiente en el Perú: siglos XVI - XX. Ministerio de Cultura, 2015

Back, Michele and Virginia Zavala. Racismo Y Lenguaje. Fondo Editorial PUCP, 2017.

Callirgos, Juan Carlos and Suzanne Oboler. El racismo peruano in Serie Diversidad Cultural, 3(1), 57-213. Ministerio de Cultura, 2013.

Chocano, Rodrigo and Sandra Rospigliosi. Patrimonio Cultural Inmaterial Afroperuano. Ministerio de Cultura, 2016.

De Deus Brito, Maíra. “As Mulheres Negras Na Mídia: Invisibilidade e Resistência”. Paper presented at the IX Seminario Internacional de Direitos Humanos da UFPB. Paraíba, 2016.

De la Cadena, Marisol. The Racial Politics of Culture and Silent Racism in Peru, n.d.

Dixon, K. and John Burdick. Comparative Perspectives on AfroLatin America. University Press of Florida, 2012

Downing, John D. H. and Charles Husband. Representing Race: Racisms, Ethnicity and the Media. SAGE Publications, 2005

Glenn, Cerise L., and Landra J. Cunningham. "The Power of Black Magic.” Journal of Black Studies, vol. 40, no. 2, Aug. 2007, pp. 135-152., doi:10.1177/0021934707307831.

Golash-Boza, T. Yo soy negro: Blackness in Peru. University Press of Florida, 2011
Greene, Shane. “Todos Somos Iguales, Todos Somos Incas: Dilemmas on Afro-Peruvian Citizenship and Inca Whiteness in Peru," in Samuel Burdick and Kwame Dixon, eds., Comparative Perspectives on Afro-Latin America. Gainesville, FL: University Press of Florida, 2012. pp. 282-304.

Hughey, Matthew W. "Cinethetic Racism: White Redemption and Black Stereotypes in 'Magical Negro' Films.” Social Problems, vol. 56, no. 3, 2009, pp. 543-577., doi:10.1525/ sp.2009.56.3.543.

Mayorga Balcazar, Lilia. Mira cómo ves: racismo y estereotipos étnicos en los medios de comunicación. Centro de Desarrollo Étnico, 2010

Ngom, M'bare, et al. "Afro-Peruvians and the Official Cultural Institutionalism: Recovering the Lost Voices." Callaloo, vol. 34, no. 2, 2011, pp. 286-506., doi:10.1353/ cal.2011.0077.

Nugent, Guillermo. El laberinto de la choledad, 1990 (manuscript).

Reiter, B. \& Kimberly E. Simmons. Afrodescendants, Identity, and the Struggle for Development in the Americas. Michigan State University Press, 2011

Schmitz, Mathias, and Agustín Espinosa. "Impacto De La Información Disonante y Consistente Sobre La Campaña Marca Perú En La Identidad Nacional y El Bienestar Social." Universitas Psychologica, vol. 14, no. 1, 2014, doi:10.11144/javeriana.upsy14-1.iidc.

Stam, Robert. Tropical Multiculturalism: A Comparative History of Race in Brazilian Cinema and Culture. Duke University Press, 1997.

Valdiviezo, Laura. "Interculturality for Afro-Peruvians: Towards a racially inclusive education in Peru” International Education Journal, vol 7, no. 1, 2006, pp. 6-35. 